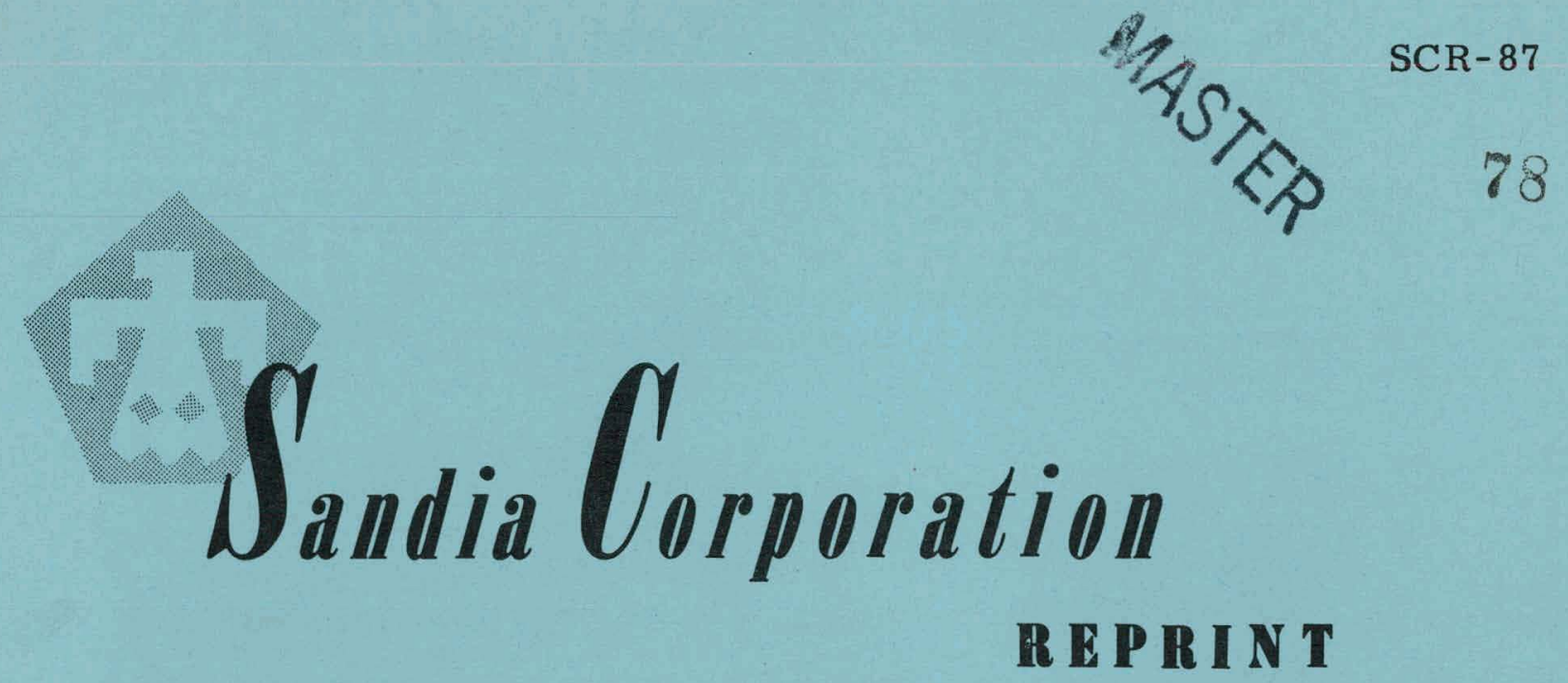

\title{
DESIGN OF A 5-INCH INTERMITTENT-FLOW \\ HIGH-TEMPERATURE HYPERSONIC WIND TUNNEL \\ by
}

Alan Pope and Randall C Maydew

May 1959 


\section{DISCLAIMER}

This report was prepared as an account of work sponsored by an agency of the United States Government. Neither the United States Government nor any agency Thereof, nor any of their employees, makes any warranty, express or implied, or assumes any legal liability or responsibility for the accuracy, completeness, or usefulness of any information, apparatus, product, or process disclosed, or represents that its use would not infringe privately owned rights. Reference herein to any specific commercial product, process, or service by trade name, trademark, manufacturer, or otherwise does not necessarily constitute or imply its endorsement, recommendation, or favoring by the United States Government or any agency thereof. The views and opinions of authors expressed herein do not necessarily state or reflect those of the United States Government or any agency thereof. 


\section{DISCLAIMER}

Portions of this document may be illegible in electronic image products. Images are produced from the best available original document. 
Preprint of a paper to be presented at the Joint AGARD Wind Tunnel Panel Supersonic Tunnel Association Meeting, Marseilles, France, September 1959

\section{LEGAL NOTICE}

This report was prepared as an account of Government sponsored work. Neither the United States, nor the Commission, nor any person acting on behalf of the Commission:

A. Makes any warranty or representation, expressed or implied, with respect to the accuracy, completeness, or usefulness of the information contained in this report, or that the use of any information, apparatus, method, or process disclosed in this report may not infringe privately owned rights; or

B. Assumes any liabilities with respect to the use of, or for damages resulting from the use of any information, apparatus, method, or process disclosed in this report.

As used in the above, "person acting on behalf of the Commission" includes any employee or contractor of the Commission, or employee of such contractor, to the extent that such employee or contractor of the Commission, or employee of such contractor prepares, disseminates, or provides access to, any information pursuant to his employment or contract with the Commission, or his employment with such contractor.

Printed in USA. Price $\$ 1.00$. Available from the Office of

Technical Services, Department of Commerce,

Washington 25, D. C. 
SCR-87

AERODYNAMICS

TID-4500 (14th Ed.)

DESIGN OF A 5-INCH INTERMITTENT-FLOW HIGH-TEMPERATURE HYPERSONIC WIND TUNNEL

\author{
by \\ Alan Pope \\ and \\ Randall C. Maydew.
}

May 1959 


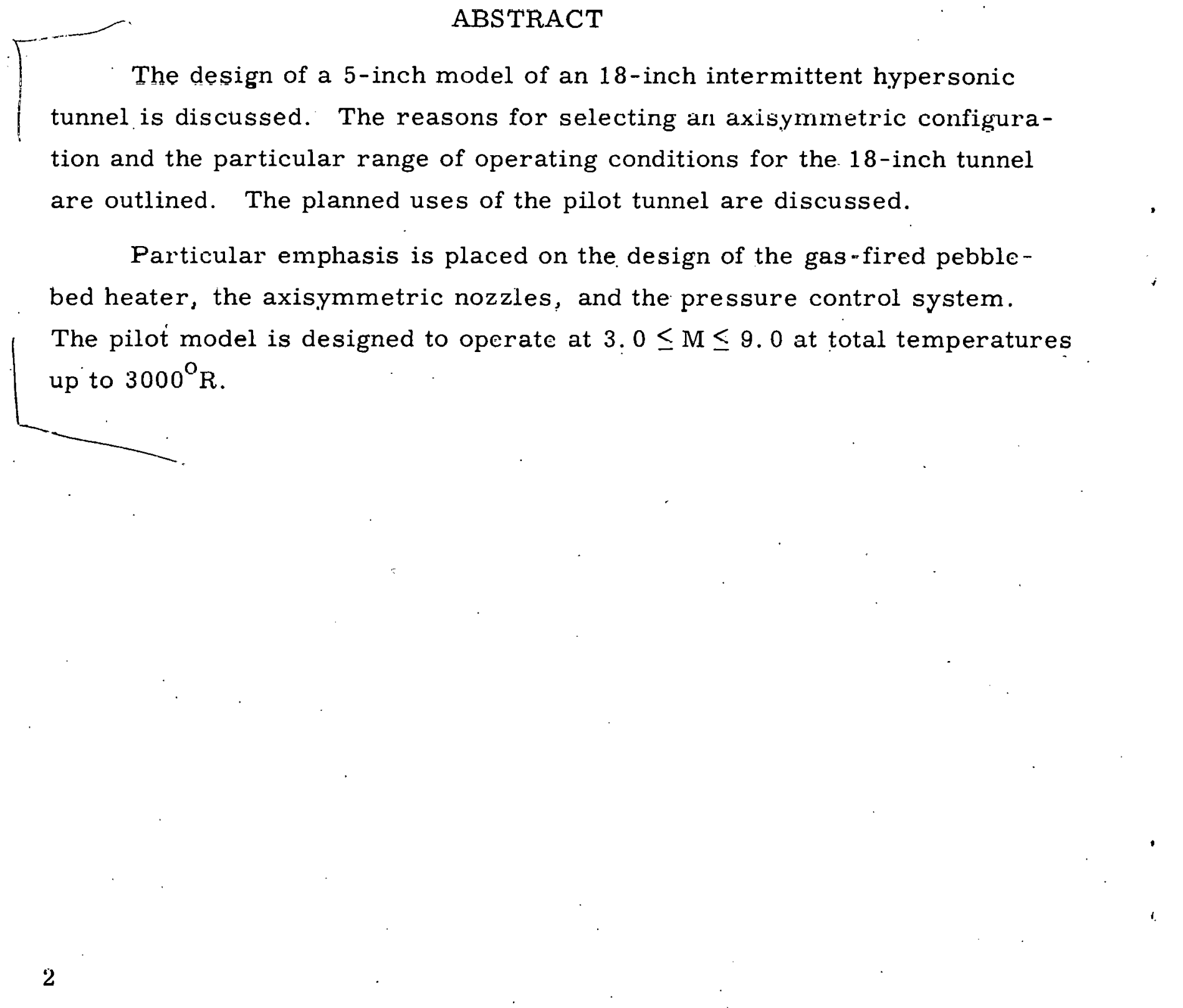


CONTENTS

$\underline{\text { Page }}$

1. INTRODUCTION . . . . . . . . . . . . . . . . . 5

2. NOMENCLATURE . . . . . . . . . . . . . 6

3. 18-INCH TUNNEL RUN-TIME CONSIDERATIONS . . . . . 9

4. GENERAL OUTLINE OF CIRCUIT . . . . . . . . . . 11

5. OPERATIONAL CYCLE. . . • • • • . • . . • . . 11

6. PEBBLE-BED HEATER . . . . . . . . . . . . 13

6.1 Heat Transfer Calculations . . . . . . . . . 13

6.2 Pressure Drop . . . . . . . . . . . . . . . 14

6.3 General Design Features . . . . . . . . . 15

6.4 Burner Control System . . . . . . . . . . . 16

7. AXISYMMETRIC NOZZLES . . . . . . • . . . 16

7.1 Nozzle Coordinates . . . . . . . . . . 16

7.2 Boundary Layer Corrections . . . . . . . . . 17

7.3 Nozzle Throat Cooling . . . . . . . . . . . 19

7. 4 Settling Chamber Design . . . . . . . . . . 21

7.5 Nozzle Fabrication . . . . . . . . . . . . 21

8. CONCLUDING REMARKS . . . . . . • • • • . . . 22

9. ACKNOWLEDGEMENTS . • • • • • • • • • • • . 22

10. REFERENCES . . . . . . . . . . . . . . 22

\section{TABLE}

I. ANTICIPATED OPERATING CONDITIONS FOR 5-INCH TUNNEL . . . . . . . . . . . . . . . . 


\section{ILLUSTRATIONS}

Figure

$\underline{\text { Page }}$

1. The Variation of Theoretical Fixed Geometry Second Throat Area with Mach Number; $\gamma=1.4$. . . . . . . . 26

2. Elevation Sketch of the 5-inch Pilot Tunnel. . . . . . . . 27

3. Schematic of 5-inch Tunnel Pressure Control System. . • . 28

4. Variation of Air Temperature with Time and Distance Parameters. . . . . . . . . . . . . . . . . . 29

5. Variation of Pebble Temperature with Time and Distance Parameters. . . . . . . . . . . . . . . . . 30

6. Variation of Pebblc and Air Temperature with Time and Heatier Station for an $\mathrm{M}=9$ Nozzle. . . . . . . . . . 31

7. Variation of Pebble and Air Temperature with Time and Heater Station for an $\mathrm{MI}=4$ Nozzle. . . . . . . . . . 32

8. Elevation Sketch of Pebble-Bed Heater. . . . . . . . . 33

9. Variation of Temperature of Beryllium-Copper Throat with Run Time (No Water Cooling). . . . . . • . . . . . 34

10. Variation of Temperature of Beryllium-Copper Throat with Run Time (With Water Cooling). . . • . • . . . . . . 35

11. Sketch of Mach 9 Axisymmetric Water-Cooled Nozzle. . . . 36 


\section{INTRODUCTION}

A study made during 1957 indicated that the number and availability of high-temperature hypersonic wind tunnels then in operation or planned for early erection in the United States were insufficient to meet the needs of the Sandia Corporation. ${ }^{*}$ Accordingly, preliminary studies were made and funds were obtained to erect a medium-sized tunnel (18-inch-diameter test section) at the Sandia Corporation in Albuquerque, New Mexico.

The hypersonic tunnel will be used to supplement the research and development testing which is being or will be conducted under contract at larger, more complex and more expensive facilities. This same concept has been used for the past 3 years with the Sandia Corporation $12-\mathrm{x} 12$-inch, intermittent transonic-supersonic tunnel; this "back-yard" facility has been utilized for "in-house" research, for short time-scale developmental testing, and for preliminary testing to decrease the amount of contract work.

The selection of the 18-inch-diameter test section was a compromise of cost considerations, utilization of the existing medium-pressure air supply (5400 $\mathrm{ft}^{3}$ at $300 \mathrm{psia}$ ), and a testing time of 30 seconds with an approximately 4 -inch-diameter model. ${ }^{* *}$ An alumina rather than a zirconia pebble-bed storage heater (maximum operating temperatures of approximately $300.0^{\circ} \mathrm{R}$ and $4500^{\circ} \mathrm{R}$, respectively) was chosen because of the greater cost of zirconia pebbles and higher temperature refractories. A natural gas heating system was selected rather than electrical firing because of the avail ability and low cost of natural gas locally. The axisymmetric tunnel configuration was selected rather than a two-dimensional configuration because of the greater over-all simplicity, greater ease of fabrication, decreased nozzle. throat distortion due to heating, elimination of several high-temperature seal problems, and the relative ease of cooling an axisymmetric tunnel.

\footnotetext{
* Sandia Corporation is a nonprofit corporation operated by Western Electric under contract to the Atomic Energy Commission.

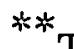

The conduction of model pressure tests at the low static pressure $(\approx 360 \mu \mathrm{Hg})$ at $\mathrm{M}=9$ requires mounting miniaturized $(0.5 \mathrm{in}$. dia. $\mathrm{x} 0.5 \mathrm{in}$. long) pressure transducers inside the model to avoid lag and outgassing; these criteria influenced the selection of model size.
} 
As the design of the hypersonic tunnel evolved, it became apparent there were several areas in which data in addition to that available were needed to aid in firming up on a final design. These areas include:

(a) Hyper sonic diffuser performance,

(b) Stagnation pressure control system,

(c) Operation of a hot quick-opening valve at the heater air exit,

(d) Reliable automatic burner control system,

(e) Methods of nozzle fabrication,

(f) Boundary layer corrections to nozzle contour, and

(g) Settling chamber mixing section.

It was decided to build a 5 -inch pilot model of the 18-inch tunnel to obtain additional design data in these areas. In addition, the pilot tunnel will provide a worthwhile research facility at an early date for calibrating total temperature probes and for evaluating heat-transfer gages, pressure transducers, water-cooled strain gage balances, and other instrumentation for use in the 18-inch tunnel.

This paper in general discusses the design of the 5 -inch tunnel with a few remarks included about the 18-inch tunnel.

2. NOIMENCLATURE

a Total pebble surface area per unit length of pebble bed, $\mathrm{ft}^{2} / \mathrm{ft}$

$d_{*} \quad$ Speed of sound at nozzle throut, $\mathrm{ft} / \mathrm{sec}$

A Cross-sectional area of pebble bed, $\mathrm{ft}^{2}$

$\mathrm{A}_{1} \quad$ Test section area, $\mathrm{ft}^{2}$

$\Lambda_{\mathrm{w}} \quad$ Cooling water annulus area, $\mathrm{ft}^{2}$

$A_{*} \quad$ Nozzle throat area, $\mathrm{ft}^{2}$

$\bar{A} \quad$ Pebble-bed flow area, $\mathrm{A} \bar{e}, \mathrm{ft}^{2}$

c Specific heat of pebbles, BTU/lb $-{ }^{\circ} \mathrm{F}=0.24$

$c_{b}$ Specific heat of beryllium-copper, BTU/lb $-{ }^{\circ} F=0.10$

$c_{p} \quad$ Specific heat of air at constant pressure, BTU/lb $-{ }^{\circ} \mathrm{F}$ 
$c_{\text {pw }}$ Specific heat of cooling water, $\mathrm{BTU} / \mathrm{lb}-{ }^{\mathrm{O}} \mathrm{F}=1.0$

d Pebble diameter, ft

$\mathrm{d}_{1}$ Inner diameter of cooling water annulus, $\mathrm{ft}$

$\mathrm{d}_{2} \quad$ Outer diameter of cooling water annulus, $\mathrm{ft}$

$d_{e} \quad d_{2}-d_{1}, f t$

D Diameter of pebble bed, ft

$D_{1} \quad$ Nozzle exit diameter, $\mathrm{It}$.

e Pebble-bed porosity, dimensionless

$\mathrm{g} \quad$ Acceleration of gravity, $\mathrm{ft} / \mathrm{sec}^{2}$

G Cooling water mass velocity, $m_{W} / A_{w}, l b / \mathrm{ft}^{2}-\mathrm{sec}$

h Pebble-air heat transfer coefficient, BTU/hr-ft ${ }^{2}-{ }^{\circ} \mathrm{F}$

$\mathrm{h}_{\mathrm{e}} \quad$ Effective pebble-air heat transfer coefficient, B'U $/ \mathrm{hr}-\mathrm{ft}^{2}-{ }^{\circ} \mathrm{F}$

$\mathrm{h}_{*} \quad$ Nozzle throat heat transfer coefficient, BTU/hr-ft ${ }^{2}-{ }^{\circ} \mathrm{F}$

$\mathrm{h}_{\mathrm{w}} \quad$ Water cooling passage film coefficient, BTU/hr-ft ${ }^{2}-{ }^{\circ} \mathrm{F}$

i Imaginary

$\mathrm{k}$ Thermal conductivity of air; BTU/hr-ft ${ }^{2}-{ }^{\circ} \mathrm{F} / \mathrm{ft}$

$\mathrm{k}_{\mathrm{b}} \quad$ Thermal conductivity of beryllium-copper, BTU/hr-ft ${ }^{2}-{ }^{\mathrm{o}} \mathrm{F} / \mathrm{ft}$

$\mathrm{k}_{\mathrm{p}}$. Thermal conductivity of alumina pebbles, BTU/hr-ft ${ }^{2}-{ }^{\mathrm{o}} \mathrm{F} / \mathrm{ft}$

$\mathrm{k}_{\mathrm{w}} \quad$ Thermal conductivity of cooling water, BTU/hr-ft ${ }^{2}-{ }^{\mathrm{o}} \mathrm{F} / \mathrm{ft}$

L : Distance along pebble bed (from entrance), ft

$\mathrm{m} \quad$ Air mass flow rate, $\mathrm{lb} / \mathrm{sec}$

$\mathrm{m}_{\mathrm{w}} \quad$ Water flow rate, $1 \mathrm{~b} / \mathrm{sec}$

M Mach number, dimensionless

n .. Shape factor of heat storage material ( 3 for spheres) or polytropic exponent 
P Pressure, $\mathrm{lb} / \mathrm{ft}^{2}$

$\mathrm{P}_{1} \quad$ Static pressure in test section, psia

$\mathrm{P}_{\mathrm{O}}$. Total pressure, psia

Pr Prandtl number, $3600 \mu \mathrm{c}_{\mathrm{p}} \mathrm{g} / \mathrm{k}$, dimensionless

q Dynamic pressure, psi

$\mathrm{r} \quad$ Radius of throat block material or pebble radius, inch or ft

$r_{i} \quad$ Inner radius of nozzle throat, inch

$r_{0} \quad$ Outer radius of throat block material, inch

$\mathrm{Re}_{\mathrm{d}}$ Reynolds number based on pebble diameter, dimensionless

$R_{x} \quad$ Reynolds number based on length, dimensionless

St. Stanton number

$t$ time, seconds or hours

$\mathrm{T}_{\mathrm{a}} \quad$ Air temperature in pebble bed, ${ }^{\mathrm{O}} \mathrm{R}$

$T_{a i}$. Initial air temperature in pebble bed, ${ }^{\circ} R$

$\mathrm{T}_{\mathrm{b}} \quad$ Temperature of nozzle throat material, $f(r, t),{ }^{o} R$

$T_{b i}$ Inner surface temperature of nozzle throat, ${ }_{R}$

$\mathrm{T}_{\mathrm{bo}}$ Outer surface temperature of nozzle throat, ${ }^{\mathrm{o}} \mathrm{R}$

$\mathrm{T}_{\mathrm{p}} \quad$ Pebble temperature, ${ }^{\mathrm{O}} \mathrm{R}$

$\mathrm{T}_{\mathrm{pi}} \quad$ Initial pebble temperature, ${ }^{\circ} \mathrm{R}$

$\mathrm{T}_{\mathrm{O}} \quad$ Air total temperature, ${ }^{\circ} \mathrm{R}$

$x \quad$ Distance from nozzle throat to exit, $\mathrm{ft}$, measured along tunnel centcrline and assumed the same along the wall or dimensionless distance parameter, Eq. 3

w Individual pebble density, $\mathrm{lb} / \mathrm{ft}^{3}$

$w_{b} \quad$ Density of nozzle throat material, $1 \mathrm{~b} / \mathrm{ft}^{3}$

$a_{b}$ Thermal diffusivity of nozzle throat material, $\mathrm{k}_{\mathrm{b}} / \mathrm{w}_{\mathrm{b}} \mathrm{c}_{\mathrm{b}}, \mathrm{ft}^{2} / \mathrm{hr}$ 
$\delta \quad$ Boundary layer thickness, inch

$\delta^{*} \quad$ Boundary layer displacement thickness, inch

$\rho \quad$ Air density in pebble bed, $\mathrm{lb} / \mathrm{ft}^{3}$

$\rho_{*} \quad$ Air density at nozzle throat, $\mathrm{lb} / \mathrm{ft}^{3}$

$\tau$... Dimensionless time parameter, Eq. 4

$\mu \quad$ Air viscosity, $1 \mathrm{~b}-\mathrm{sec} / \mathrm{ft}^{2}$

$\mu_{\mathrm{w}} \quad$ Water viscosity, $\mathrm{lb}-\mathrm{sec} / \mathrm{ft}^{2}$

\section{18-INCH TUNNEL RUN-TIME CONSIDERATIONS}

One of the major problems with intermittent wind tunnels is that of run time--both the selection of the proper run time and the realization of the selected times. A minimum of 30 seconds was selected for the 18-inch tunnel on the basis that this time would be sufficient for a force test polar, pressure measurements at very low static pressures, dynamic stability tests, and model heat-transfer measurements. The vacuum storage capacity was dictated by the 30-second run-time criteria, the diffuser efficiency anticipated, the Mach number range $(3 \leq M \leq 9)$, and stagnation temperature and pressure conditions (maximums of $3000^{\circ} \mathrm{R}$ and $275 \mathrm{psia}$, respectively). A fixed rather than an adjustable diffuser was chosen because considerable additional vacuum storage can be provided for the cost of an adjustable diffuser; the gain in run times due to adding vacuum storage is much more certain. It was initially decided to provide interchangeable fixed diffusers for each nozzle, $M=3,4,5,7$ and 9 . However, examination of the ratio of theoretical minimum second throat area to test section area over the Mach number range of 3 to 9 (Figure 1) indicates an area change of only 11 percent. Hence, it was decided to investigate the feasibility of using a single fixed diffuser over the complete Mach number range. Various supersonic diffuser configurations (varying convergence angle, throat diameter, and throat length) will be tested in the pilot tunnel to arrive at a satisfactory configuration for the 18-inch tunnel.

An additional run-time consideration is the method of aftercooling used. Spray cooling, air-to-water heat exchanger, and heat sink material were 
considered. Spray cooling was discarded because of a decreased run time due to the higher pressure air vapor mixture in the vacuum tanks and because of the increased pumping time required to remove the vapor from the tanks. The required size and cost and the possibility of leaks ruled out the tubular heat exchanger.

Experience with heat storage material in the pressure storage system * indicated that the expansion process during a 30-second or so test (at mass flow rates from approximately 20 to $100 \mathrm{lb} / \mathrm{sec}$ ) in the transonic-supersonic circuit was nearer isothermal than adiabatic (an $\mathrm{n} \approx 1.1$ was achieved using heat storage material). The temperature drop ${ }^{* *}$ before the can installation was from $70^{\circ}$ to $150^{\circ} \mathrm{F}$ and from $5^{\circ}$ to $30^{\circ} \mathrm{F}$ after the installation. A fairly efficient forced convection heat transfer process is achievable, with only a 3 -percent loss in storage volume, because of the large ratio of can surface area to weight. In spite of the 3-percent loss, the run time is slightly increased since more energy is available.

This favorable experience with cans as a heat storage material led to the design consideration of placing cans in the first vacuum tank to aftercool the hypersonic tunnel exhaust. It is believed that a reasonable forced convection heat transfer process can be achieved because of the high initial exhaustto-can temperature potential even though the mass flow rates (and heat transfer coefficients) are relatively low. Approximately one hundred thousand 1/4gallon replaceable-lid ${ }^{\dagger}$ tin cans $(34,000 \mathrm{lbs})$ will be installed in the first vacuum tank. The cans will be supported in a grid 2-1/2 feet above the 30-inch jet exhaust; a conical deflector at the exit will spread the jet to distribute the heat over a large number of cans. The cost of the cans is approximately $\$ 6000$.

\footnotetext{
* Both 2600-cubic-foot storage tanks are filled with tin cans.

* The amount of temperature drop depends upon the daily ambient temperature, mass flow rate, run time, etc.

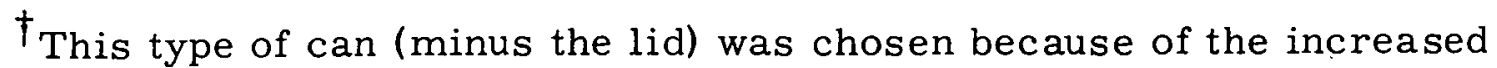
structural rigidity; it will not crush due to the weight of the upper column of cans.
} 
This heat sink method of aftercooling should considerably increase the run time-especially for the high stagnation temperature operating conditions. These run-time considerations, tunnel size, operating conditions, the anticipated diffuser efficiency, and cost considerations led to the choice of the 30,000 cubic feet of vacuum storage. The vacuum system consists of three 10,000 cubic feet Hortonspheres evacuated to an absolute pressure of 0.2 psia.

\section{GENERAL OUTLINE OF CIRCUIT}

An elevation skctch of the 5-inch tunnel is presented in Figure 2. In general, it is a "railroad" type intermittent pressure-vacuum tunnel with the settling chamber, nozzle, test section, instrumentation section, and diffusers mounted on lathe-bed ways; the diffuser telescopes into the 10-inch vacuum line. The telescoping feature, plus the quick-disconnect Marman clamps (see detail, Figure 2), provides an optical bench-type setup for easy installation of models and instrumentation, plus a quick interchange of nozzles, diffusers, etc. Metal seals are used at the Marman clamp joints.

Other features of the tunnel include a gas-fired alumina pebble-bed storage heater, a rather flexible stagnation pressure control system, axisymmetric nozzles with integral settling chambers, and a fixed supersonic diffuser set for acceptable starting and operation at the lowest Mach number.

\section{OPERATIONAL CYCLE}

The design of a pressure control system for a pebble-bed-heater-type intermittent tunnel is a compromise of the following requirements:

(a) Minimum time to establish steady flow conditions because of the limited pressure and vacuum storage capacity,

(b) Prevention of pebble lifting during the transient starting process, and,

(c) Maintenance of a constant stagnation pressure during the testing period for a wide range of stagnation pressures and mass flow rates. 
The anticipated range of operating conditions is presented in Table I. Note that the range of stagnation pressures and mass flow rates varies from 10 to 275 psia and from 0.05 to $3.6 \mathrm{lb} / \mathrm{sec}$, respectively.

An operationally flexible pressure control system (Figure 3) has been developed for the 5 -inch tunnel; this system will be utilized, experimenting with various starting modes, to ascertain a satisfactory starting method for the 18-inch tunnel. Two starting methods (with valves $A, G_{1}, G_{2}, E_{1}$ closed and $P_{1}$ open) are:

(a) Vacuum (0.2 psia) in the heater at the start: with $R_{2}$ closed, preset $R_{1}$ partially open and then open $V_{1}$ and $Q_{2}$; open $Q_{1}$ and manually control $R_{1}$ (with remote observation of the pebble motion through the sight glass) until the desired stagnation pressure is reached; then switch to automatic controlling. This method will result in long starting times; however, valves $R_{2}$ and probably $Q_{1}$ could be eliminated and the "hot valve" $\mathrm{Q}_{2}$ would not have to be a quickopening valve.

(b) Stagnation pressure in the heater at the start: preset $R_{1}$ and prepressurize the heater to stagnation pressure with regulator $\mathrm{R}_{2}$; open vacuum valve $\mathrm{V}_{1}$; open $\mathrm{Q}_{1}$ and $\mathrm{Q}_{2}$ (closing $\mathrm{R}_{2}$ at the same time) and switch to automatic controlling with $R_{1}$ as soon as the desired stagnation pressure is reached. This method should require the least time to start with a losser shanre of lifting the pebbles; however "hot valve" $Q_{2}$ must be quickopening.

Recent studies have indicated that other types of quick-opening valves (such as 1/4-turn ball) may function more satisfactorily for $Q_{2}$ than a butterfly valve. Heating of the butterfly flapper during a run and the effect of the flapper wake on the flow uniformity in the settling chamber are serious problems. A butterfly valve will not be used at $Q_{2}$ in the 18 -inch tunnel.

There are many variations of the two methods outlined for starting the pilot tunnel with this pressure control system. Various starting methods will 
be tried although it is believed that method (2) will prove to be the most feasible. Other pressure control system considerations include minimizing the thermal shock on the pebbles, loss of bed heat during starting process, and loss of heat from heater outlet to settling chamber.

\section{PEBBLE-BED HEÄTER}

\section{1 Heat Transfer Calculations}

The height of a pebble bed is primarily dictated by a specification on the allowable air temperature drop at the heater exit during a specified testing timc; the specified run tinte fur the pilot tunnel is 30 seconds. 'I'he heat transferred to the air is a function of the pebble material, pebble diameter, bed diameter, mass flow rate, and run time as well as the bed height.

The equations relating the air and pebble temperature as a function of time and distance along the bed can be expressed as (Liu, et al ${ }^{1}$ ):

$$
\begin{aligned}
& f(\tau, x)=\frac{T_{p i}-T_{a}}{T_{p i}-T_{a i}}=1-\int_{0}^{x} e^{-(\tau+x)} J_{0}(2 i \sqrt{\tau x}) d x \\
& g(\tau, x)=\frac{T_{p}-T_{a i}}{T_{p i}-T_{a i}}=1-\int_{0}^{\tau} \cdot e^{-(\tau+x)} J_{o}(2 i \sqrt{\tau x}) d \tau
\end{aligned}
$$

where

$$
\begin{aligned}
x & =h_{e} a L / c_{p} m \\
\tau & =n h_{e} t / w c r
\end{aligned}
$$

and

$J_{0}(2 i \sqrt{\tau x})$ is a Bessel function of the first kind of zero order.

Equations 1 and 2 were solved by programming a series expansion of the integrals on an IBM 704: Graphical'solutions of Equations 1 and 2 are presented in Figures 4 and 5, respectively, for $3 \leq \tau \leq 15$. Solutions of these equations, for a wider range of the independent variables $\tau$ and $x$, 
have been tabulated by Steck. ${ }^{2}$ The results of sample calculations of the air and pebble temperature are presented in Figures 6 and 7 . These calculations were performed for a 14-inch-diameter bed filled with 3/4-inchdiameter alumina pebbles; it was assumed that the initial temperature of the bed was uniform. The effective heat transfer coefficient $\left(h_{e}\right)$ used for the se calculations is:

where

$$
h_{e}=\frac{1}{\frac{1}{h}+\frac{d}{2 k}}
$$

$$
\mathrm{h}=\left(\frac{0.56 \mathrm{k}}{\mathrm{d}}\right) \operatorname{Re}_{\mathrm{d}}^{0.6} \cdot \operatorname{Pr}^{1 / 3}
$$

with the air properties evaluated at the local air temperatures.

\subsection{Pressure Drop}

The high-pressure air is introduced at the base of the vertical pebblebed heater; the pressure drop (per unit length of bed) must be sumewhal luss than the bed bulk density " to prevent the pebbles from lifting during a test. Specification of mass flow rate, pebble characteristics, and air density dictates the minimum bed diameter which can be considered.

Bloom ${ }^{3}$ gives the following expression for calculating the pressure drop through pebble beds:

$$
\frac{\mathrm{dP}}{\mathrm{dL}}=2.4\left(\frac{\mathrm{Re}_{\mathrm{d}}}{6}\right)^{-0.1}\left(\frac{1-\overline{\mathrm{e}}}{\overline{\mathrm{e}}}\right) \frac{\mathrm{m}^{2}}{\rho g \mathrm{~d} \overline{\mathrm{A}}^{2}}
$$

Bloom ${ }^{3}$ states that the probable accuracy of Equation 7 is \pm 35 percent. The pressure drop across a simulated pebble-bed heater (a 14-inch column of 0.62 -inch-diameter-glass marbles in a 7.5-inch-diameter lucite cylinder) was measured ${ }^{4}$ at several mass flow rates to determine the validity of Equation 7 .

"The bulk density is defined as $(1-\mathrm{e}) \mathrm{w}, \mathrm{lb} / \mathrm{ft}^{3}$. 
The data indicate that Equation 7 underestimates the pressure drop by approximately 18 percent; the data correlate well with the experimental data of Carman. ${ }^{5}$ The test results indicated the upper layer of pebbles started spinning and lifting at a pressure drop (per unit length of bed) equal to 80 and 85 percent, respectively, of the bed bulk density. Obviously the static pressure gradient does not account for the total lift on individual pebbles.

Preliminary information obtained from vendors indicated the porosity of a pebble bed is approximately 48 to 50 percent for spherical pebbles. Calculations and measurements indicated the porosity varies from 35 to 40 percent for diameter ratios usually associated with pebble-bed heater design-D/d of 10 to 40 , respectively. These porosity data agree with data presented by Carman. 5

This information on porosity and pressure drop (along with the heat . transfer considerations for sizing the bed height) was used to size the diameter of the heater pebble bed for the pilot tunnel.

\section{3 General Design Features}

A cutaway elevation of the pebble-bed heater is presented in Figure 8 . The over-all assembly is 34 inches in diameter and approximately 12 feet high. A pyrex sight glass assembly is provided for observation and adjustment of the flame during burning and for observation of the pebble movement during starting and operation of the tunnel. Cooling water coils are provided at the air entrance, air exit, and sight glass assembly with spray cooling at the heater base. The calculated heater shell temperature is $350^{\circ} \mathrm{F}$; water drip cooling of the heater shell may be provided at a later date. Quickdisconnect Marman clamps are used for burner dome attachments, the entrance air header, and the air exit. The metal-ceramic pebble support grate is designed to support the column of pebbles at a temperature of $2500^{\circ} \mathrm{F}$. Eight thermocouple wells are provided for measurement of bed temperature. Dry pack insulation is provided to allow for differential expansion of the layers of refractory material. 


\subsection{Burner Control System}

The burner capacity is $0.30 \times 10^{6} \mathrm{BTU} / \mathrm{hr}$; the system is completely automatic with push-button controls for the heating or testing cycles. The system is interlocked with the various air valves, cooling water valves and flow-meters, turbo blower, purge timer, gas valves, etc., to insure the proper sequencing of events for either the heating or testing cycles. An abbreviated sequence of operations for the heating cycle is as follows:

1. Valves $Q_{1}, Q_{2}, R_{2}$ (see Figure 3 ) are closed and exhaust valve $\mathrm{E}_{1}$ is opened,

2. The cooling water to the coils at the air entrance, air exit, and sight glass must be flowing,

3. Alr is supplied by a turbo blower to purge the heater before starting the burner,

4. After purging, the ignition plug sparks, the pilot gas solenoid valve $G_{2}$ opens, the pilot flame is ignited, and the spray water is turned on; when the pilot flame contacts the flamerod, the main gas solenoid valve $G_{1}$ opens; the air-gas proportioning valve is preset to give the desired burning rate, and

5. The burner is automatically shut off when the pebble-bed control thermocouple senses the desired temperature, and the heating cycle begins again when the bed temperature drops below the prescribed limit.

Dilution air is provided as an additional control of the temperature of the combustion products passing through the bed.

\section{AXISYMMETRIC NOZZLE}

\section{1 Nozzle Coordinates}

The method of Foelsch ${ }^{6}$ was programmed on the IBM 704 to calculate coordinates for the nozzles. This method converts the flow from a plane circular section at the throat into conical source flow which is then transformed into a parallel stream of uniform velocity by an approximation to 
the method of characteristics. Equations ${ }^{7}$ accounting for imperfect-gas effects were included in the IBM 704 program to correct the coordinate determination for the local flow conditions along the nozzle. A radius of curvature at the throat of ten times the throat radius and an included cone angle of 12 degrees were used ${ }^{*}$ in the calculations. The effect of considering real gas on the area ratio for a total temperature of $3000^{\circ} \mathrm{R}$ is

$$
\begin{aligned}
& \frac{M}{7} \quad \frac{A_{1} / A_{*}}{129.1} \text { (real) } \quad \frac{A_{1} / A_{*}}{104.1} \text { (perfect) } \\
& 9 \quad 405.5 \quad 327.2
\end{aligned}
$$

The method of characteristics is presently being programmed on the IBM 704 for determination of coordinates for all future nozzles.

\section{2 Boundary Layer Corrections}

The stabilizing influences of a favorable pressure gradient and cold nozzle walls should insure a laminar run up to a Reynolds number (based on distance from the nozzle throat to exit) on the order of $2 \times 10^{6}$.

Initial estimations of boundary layer growth along the nozzles were made using Van Driest's ${ }^{8}$ theory, which considers the effects of heat transfer and compressibility on the laminar boundary layer development on a flat plate. The displacement thickness $\left(\delta^{*}\right)$ was calculated for conditions at the nozzle exit (assuming $\delta^{*}=0$ at the throat) for an assumed wall temperature of $200^{\circ} \mathrm{F}$; a linear growth of $\delta^{*}$ with $\mathrm{x}$ was assumed. Estimations of the boundary layer

\footnotetext{
* 12 degrees has been used successfully by others. ***iowever, Dr. T. Smith, BRL, Aberdeen Proving Grounds recently verbally related that turbulent boundary layer profiles had been measured at approximately the same Reynolds number, in their model hypersonic tunnel at the California Institute of Technology.
} 
thickness at the exit of an $M=9$ nozzle $\left(D_{1}=4.94\right.$ inches and $x=3.05$ feet $)$ for several operating conditions are:

\begin{tabular}{|c|c|c|c|c|c|c|}
\hline Condition & M & $\mathrm{T}_{\mathrm{O}^{\prime}}{ }^{\mathrm{o}} \mathrm{R}$ & $\begin{array}{c}\mathrm{P}_{\mathrm{o}} \\
\text { (psia) }\end{array}$ & $\operatorname{Re}_{x} \times 10^{-6}$ & $\begin{array}{c}\delta^{*} \\
\text { (in.) }\end{array}$ & $\begin{array}{c}\delta \\
\text { (in.) }\end{array}$ \\
\hline 1 & 9.0 & 3000 & 150 & 0.43 & 0.61 & 0.84 \\
\hline 2 & 9.0 & 3000 & 275 & 0.79 & 0.45 & 0.62 \\
\hline 3 & 9.0 & $1480^{*}$ & 150 & 1. 34 & 0.54 & 0.58 \\
\hline 4 & 9.0 & 1480 & 275 & 2.46 & 0.34 & 0.43 \\
\hline
\end{tabular}

These values of $\delta^{*}$ and $\delta$ are probably on the order of 10 to 20 percent too high since the boundary layer will thin in the actual three-dimensional case due to the streamline divergence. The displacement thickness calculated for "Condition 2 " was used to correct the nozzle coordinates calculated by the Foelsch method. Noting the variation of $\delta^{*}$ at exit with operating conditions (and the probable inaccuracy of predicting $\delta^{*}(x)$ for a single operating condition) leads one to speculate on the interrelationship of the following additional design considerations for obtaining the optimum uniform test section flow:

1. Use of the more exact method of characteristics rather than the Foelsch method for nonviscous flow coordinate determination,

2. Consideration of real gas effects,

3. Nozzle fabrication tolerances associatcd with electroforming versus lathe-boring in sections (Are tolerances of 0.0002 in. or even 0.001 in. really meaningful or necessary?), and

4. Thermal distortion of the nozzle throat.

The method of Cohen and Reshotko ${ }^{9}$ (which considers the effects of compressibility, heat transfer, and moderate pressure gradients in axisymmetric flow) is presently being used for supplementary boundary layer

\footnotetext{
A total temperature of approximately $1480^{\circ} \mathrm{R}$ is needed to avoid liquefaction.
} 
corrections. However, use of this method requires extension from their exact method for large favorable pressure gradients; the accuracy of such extensions is not known.

\section{3 Nozzle Throat Cooling}

The equation of conduction in cylindrical coordinates at the nozzle throat can be expressed as

$$
\frac{\partial \mathrm{T}_{\mathrm{b}}}{\partial \mathrm{t}}=a_{\mathrm{b}}\left[\frac{\partial^{2} \mathrm{~T}_{\mathrm{b}}}{\partial \mathrm{r}^{2}}+\frac{1}{\mathrm{r}} \frac{\partial \mathrm{T}}{\partial \mathrm{r}}\right]
$$

with the initial condition

$$
\mathrm{T}_{\mathrm{b}}(\mathrm{r}, \mathrm{o})=540^{\circ} \mathrm{R}
$$

and the boundary conditions

Case I - no water cooling

$$
\begin{aligned}
& -\left.k_{b} \frac{\partial T_{b}}{\partial r}\right|_{r_{i}}=h_{*}\left(T_{o}-T_{b i}\right) \\
& -\left.k_{b} \frac{\partial T_{b}}{\partial r}\right|_{r_{o}}=0
\end{aligned}
$$

Case II - water cooling

$$
\begin{aligned}
& -\left.k_{b} \frac{\partial T_{b}}{\partial r}\right|_{r_{i}}=h_{*}\left(T_{o}-T_{b i}\right) \\
& -\left.k_{b} \frac{\partial T_{b}}{\partial r}\right|_{r_{o}}=h_{w}\left(T_{w}-T_{b o}\right)
\end{aligned}
$$

where

$$
\mathrm{h}_{*}=3600 \text { St } \rho_{*} \mathrm{a}_{*} \mathrm{c}_{\mathrm{p}}=5.04 \rho_{*} \mathrm{a}_{*} \mathrm{c}_{\mathrm{p}}
$$


Smelt ${ }^{10}$ recommends using a Stanton number of 0.0014 , which is the equivalent of assuming turbulent ${ }^{*}$ flow at the throat.

The film coefficient for the annular water-cooling passages according to Knudsen and Katz ${ }^{11}$ is

$$
h_{w}=0.023\left(\frac{k_{w}}{d_{e}}\right)\left(\frac{d_{e} G}{\mu_{w}^{g}}\right)^{0.8}\left(\frac{3600 \mu_{w} c_{p w} g}{k_{w}}\right)^{0.4}\left(\frac{d_{2}}{d_{1}}\right)^{0.45} .
$$

where the fluid properties are evaluated at the bulk temperature.

'The assumptions made which might huve a significant effect on the accuracy of these calculations are:

1. The equations used to calculate $h_{\dddot{r}}$ and $h_{w}$ and

2. The effect of longitudinal conduction.

Equations 8 through 13 were programmed on a Reeves Analog Computer to obtain the temperature distribution as a function of time through a beryllium-copper throat. The results of these calculations are presented in Figures 9 and 10 for the no-cooling and water-cooled cascs, respectively, where it is seen that nozzle heating is not a serious problem since throat temperatures will not exceed $400^{\circ} \mathrm{F}$. Water cooling will be provided in order to reduce thermal distortion.

\footnotetext{
This assumption of turbulent flow is inconsistent with previous statements of the existence of a laminar boundary layer; however, use of the turbulent value of Stanton number should result in a conservative solution. In addition, the tedious and difficult computation of the boundary layer growth from the heater exit to the nozzle throat is avoided.
} 


\section{4 Settling Chamber Design}

The pebble-bed heater air outlet was sized to a diameter of 6 inches in order to keep the flow velocity relatively. low for the largest mass flow rate condition (to minimize erosion of the Carbofrax liner). However, at the very low mass flow rates associated with the $M=7$ and 9 nozzles, $a$ 6 -inch-diameter settling chamber would result in such low velocities that free convection heat transfer would cause large vertical temperature gradients across the settling chamber. Hence, it was decided to provide interchangeable settling chambers with each nozzle to decrease these free convection effects. The settling chamber diameters and resulting flow conditions for a 4.93-inch-diameter test section are:

\begin{tabular}{|c|c|c|c|c|c|c|}
\hline M & $\begin{array}{l}\mathrm{T}_{\mathrm{O}^{\prime}}{ }^{\mathrm{O}} \mathrm{R} \\
(\mathrm{max}) \\
\end{array}$ & $\begin{array}{l}\mathrm{T}_{\mathrm{O}^{\prime}}{ }^{\mathrm{O}_{\mathrm{R}}} \\
(\mathrm{min})^{*} \\
\end{array}$ & $\begin{array}{c}\text { Settling chamber } \\
\text { diameter } \\
\text { (in) }\end{array}$ & $\begin{array}{c}\text { Contraction } \\
\text { ratio } \\
\end{array}$ & $\begin{array}{l}\text { Settling } \\
\text { velocit } \\
\text { (max) }\end{array}$ & $\begin{array}{l}\text { hamber } \\
\text { (ft/sec) } \\
(\text { min) }\end{array}$ \\
\hline 4 & $2180^{* * *}$ & 580 & 6 & 15 & 91 & 47 \\
\hline 5 & 3000 & 660 & 4.5 & 19 & 81 & 38 \\
\hline 7 & 3000 & 1020 & 2.0 & 18 & 89 & 52 \\
\hline 9 & 3000 & 1480 & 1.5 & 39 & 41 & 28 \\
\hline
\end{tabular}

\section{5 Nozzle Fabrication}

Methods of nozzle fabrication which have been considered are electroforming over a mandrel, high-pressure casting over a mandrel, and latheboring in sections from castings or billets. The latter method is being used to fabricate the $M=9$ nozzle shown in Figure 11. It is planned to use the electroforming method at a later date.

\footnotetext{
* The minimum values were selected as being just high enough to avoid liquefaction.

** Although the tunnel is capable of higher temperatures, $2180^{\circ} \mathrm{R}$ was selected as a maximum for $M=4.0$ since it represents the stagnation value at sealevèl flight conditions.
} 


\section{CONCLUDING REMARKS}

(a) The design of the 5-inch intermittent-flow, high-temperature hypersonic tunnel was, of necessity, dictated by the proposed usage, cost considerations, and the utilization of an existing pressure storage system; many of the design decisions made were a result of compromise of these considerations.

(b) Operation of tunnel (presently scheduled to start in October or November 1959) will provide answers on the validity of the design criteria presented herein and additional data to finalize the design of the 18-inch tunnel.

(c) Although a number of decisions were made by estimations, the design of a hot intermittent-flow hypersonir: wind tunnel appears amenable to direct mathematical and engineering procedures.

\section{ACKNOWLEDGEMENTS}

The author's are indebted to the personnel of the Experimental and Design Aerodynamics Divisions, Sandia Corporation, for their design assistance. Particular thanks are due D. E. Randall, J. C. Weydert, S. S. Millwright, and K. L. Goin.

\section{REFERENCES}

1. Liu, T. S., et al, "Construction of a Wind. Tunnel Simulating the Aerodynamic Heating Effects on Aircraft Structures", ARDC USAF, WADC TR 56-215, 1956.

2. Steck, G. P., "Uses of the Tables of the Circular Coverage Function", Sandia Corporation 'l'echnical IVlemorandum ż 14-58̈(51), July 1958.

3. Bloom, M. H., "A High Temperature-Pressure Air Heater (Suitable for Intermittent Hypersonic Wind-Tunnel Operation)", WADC-TN55-694, November 1956. 
4. Randall, D. E., and Millwright, S. S., "Experimental Determination of the Pressure Drop Through a Pebble Bed", Sandia Corporation Research Report (to be published).

5. Carman, P. C., "Fluid Flow Through Granular Beds", Transactions Institution of Chemical Engineers (London), Vol. 15, pp. 15̣0, 1937.

6. Foelsch, Kuno, "The Analytical Design of an Axially Symmetric Laval Nozzle for a Parallel and Uniform Jet", JAS, March 1949 .

7. Ames Research Staff "Equations, Tables and Charts for Compressible Flow", NACA TR 1135, 1953.

8. Van Driest, E. R., "Investigation of the Laminar Boundary Layer in Compressible Fluids Using the Crocco Method", NACA TN 2597, 1952 .

9. Cohen, C. B., and Reshotko, "The Compressible Laminar Boundary Layer With Heat Transfer and Arbitrary Pressure Gradient", NACA TR 1294, 1956.

10. Smelt, R., "Test Facilities for Ultra-High-Speed Aerodynamics", AEDC-TR-55-6, June 1955.

11. Knudsen, J. G. , and Katz, D. L. " "Fluid Dynamics and Heat Transfer", McGraw-Hill Book Co., Inc. , 1958. 
TABLE I

ANTICIPATED OPERATING CONDITIONS FOR 5-INCH TUNNEL

A. Maximum total pressure and total temperature

\begin{tabular}{|c|c|c|c|c|c|c|}
\hline $\mathrm{M}$ & $\mathrm{T}_{\mathrm{O}},{ }^{\mathrm{O}} \mathrm{R}$ & $\mathrm{P}_{0}$, psia & $\mathrm{m}, \mathrm{lb} / \mathrm{sec}$ & q, psi & $\mathrm{P}_{1}$, psia & $\mathrm{Re} / \mathrm{ft} \times 10^{-6}$ \\
\hline $3^{*}$ & 1450 & 16.3 & 0.65 & 2.8 & 0.44 & 0.64 \\
\hline 4 & 2180 & 46.7 & 0.90 & 3.5 & 0.31 & 0.59 \\
\hline 5 & 3000 & 268 & 1.89 & 8.9 & 0.51 & 1.27 \\
\hline 7 & 3000 & 275 & 0.42 & 2.3 & 0.066 & 0.51 \\
\hline 9 & 3000 & 275 & 0.11 & 0.74 & 0.013 & 0.26 \\
\hline
\end{tabular}

B. Maximum total pressure and minimum total temperature

$\begin{array}{rrrlllc}3 & 580 & 18.3 & 1.16 & 3.1 & 0.50 & 2.59 \\ 4 & 580 & 55.3 & 2.07 & 4.1 & 0.36 & 4.63 \\ 5 & 660 & 275 & 3.56 & 9.1 & 0.52 & 11.9 \\ 7 & 1020 & 275 & 0.76 & 2.3 & 0.066 & 2.7 \\ 9 & 1480 & 275 & 0.17 & 0.74 & 0.013 & 0.81\end{array}$

C. Minimum total pressure and maximum total temperature

$\begin{array}{rrrrlll}3 & 1450 & 10 & 0.40 & 1.72 & 0.27 & 0.39 \\ 4 & 2180 & 20 & 0.38 & 1.48 & 0.13 & 0.25 \\ 5 & 3000 & 20 & 0.12 & 0.66 & 0.038 & 0.095 \\ 7 & 3000 & 50 & 0.06 & 0.41 & 0.012 & 0.093 \\ 9 & 3000 & 150 & 0.05 & 0.40 & 0.0071 & 0.14\end{array}$

\footnotetext{
"A 4-inch-diameter test section will be used at $M=3$; the test section size is
} limited by allowable pressure drop through the heater. 
TABLE I (cont)

D. Minimum total pressure and total temperature

\begin{tabular}{|c|c|c|c|c|c|c|}
\hline $\mathrm{M}$ & $\mathrm{T}_{\mathrm{O}},{ }^{\mathrm{o}} \mathrm{R}$ & $\mathrm{P}_{\mathrm{o}}, \mathrm{psia}$ & $\mathrm{m}, \mathrm{lb} / \mathrm{sec}$ & q, psi & $\mathrm{P}_{1}$, psia & $\mathrm{Re} / \mathrm{ft} \times 10^{-6}$ \\
\hline 3 & $580^{\circ}$ & 10 & 0.63 & 1.72 & 0.27 & 1.38 \\
\hline 4 & 580 & 20 & 0.73 & 1.48 & 0.13 & 1.66 \\
\hline 5 & 660 & 20 & 0.28 & 0.66 & 0.038 & 0.86 \\
\hline 7 & 1020 & 50 & 0.12 & 0.41 & 0.012 & $0.50^{\circ}$ \\
\hline 9 & 1480 & 150 & 0.082 & 0.40 & 0.0071 & 0.44 \\
\hline
\end{tabular}




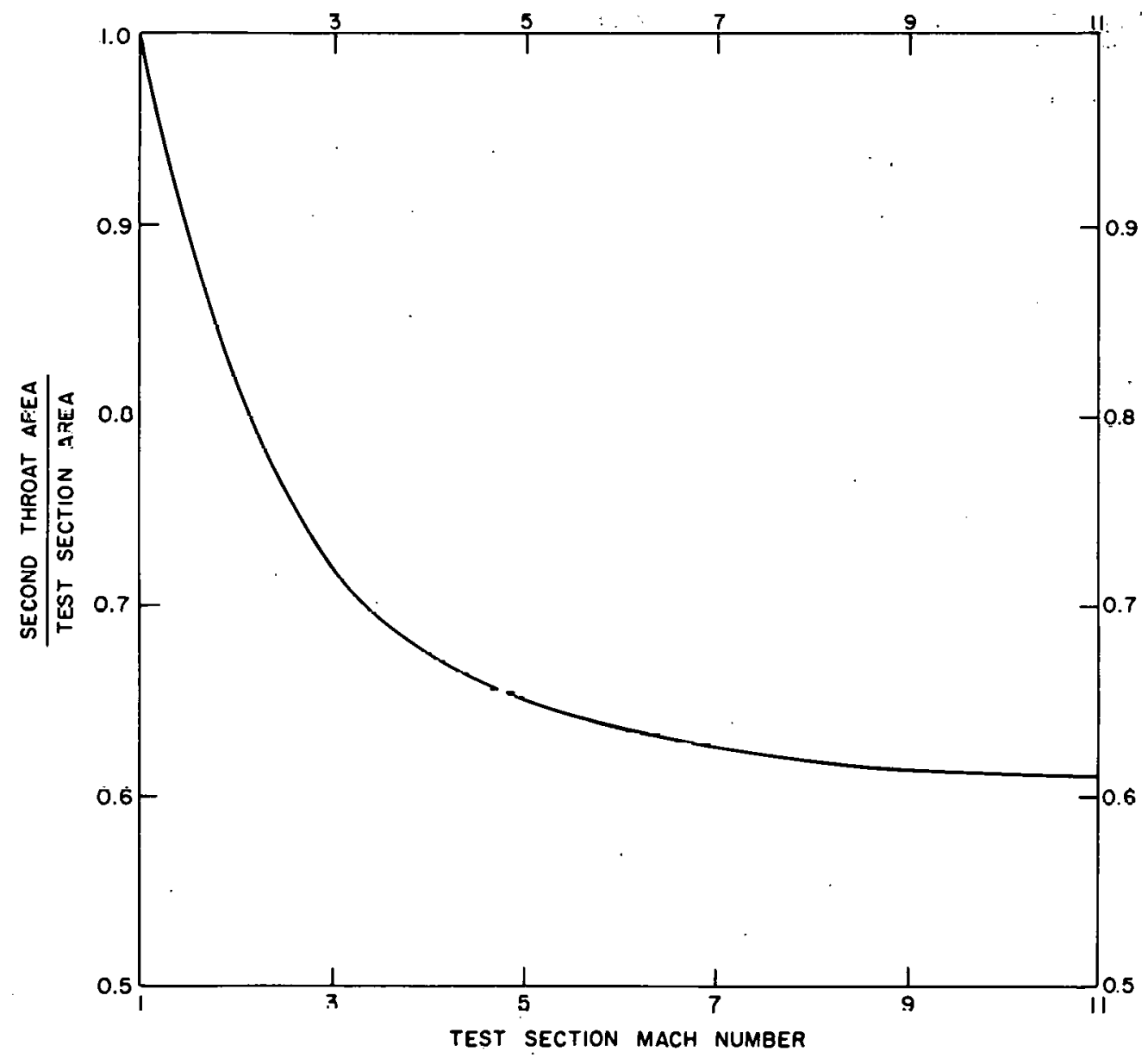

Figure 1. The Variation of Theoretical Fixed Geometry Second Throat Area with Mach Number; $\gamma=1.4$ 


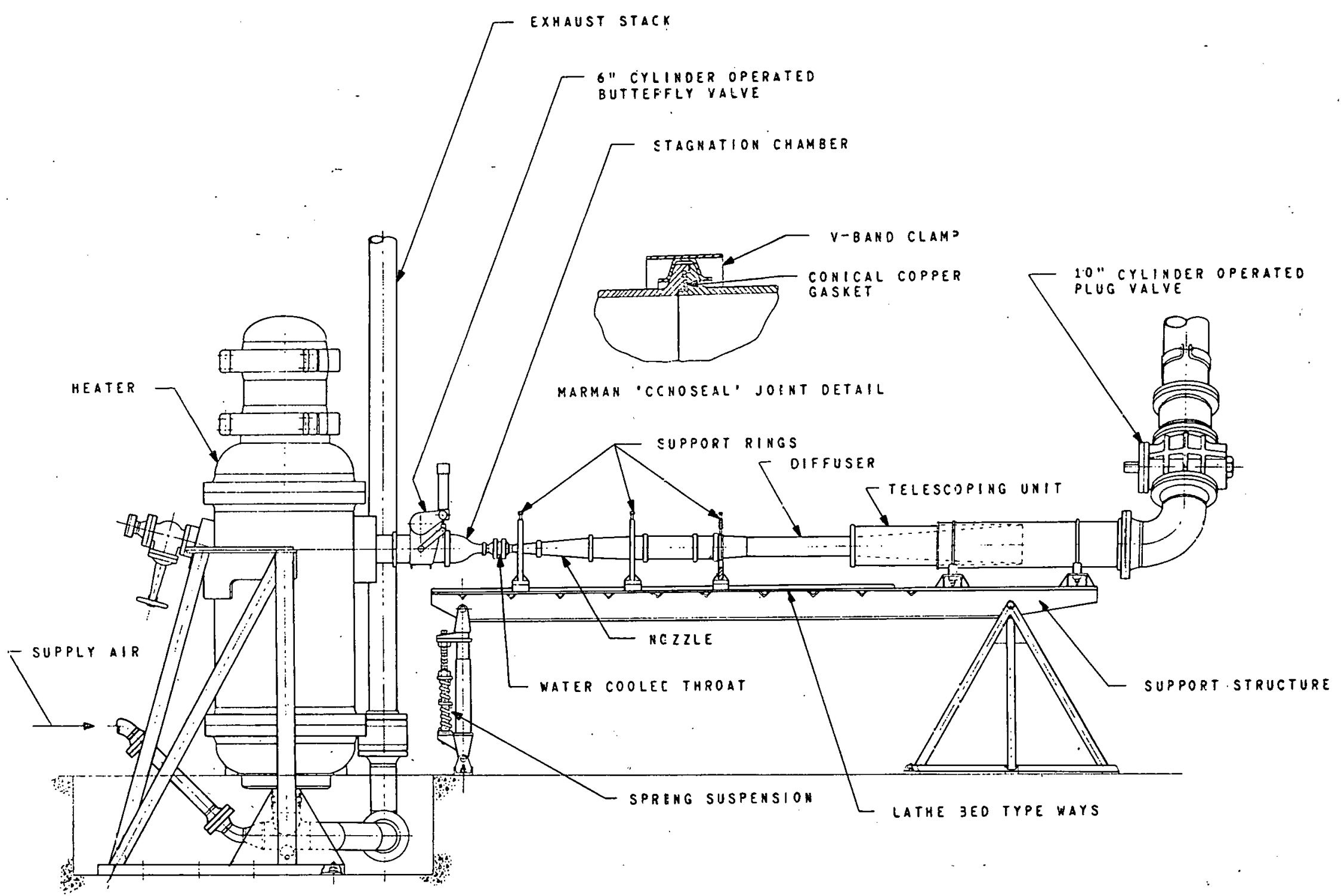

Figure 2. Elevation Sketch of the 5-inch Pilot Tunnel 


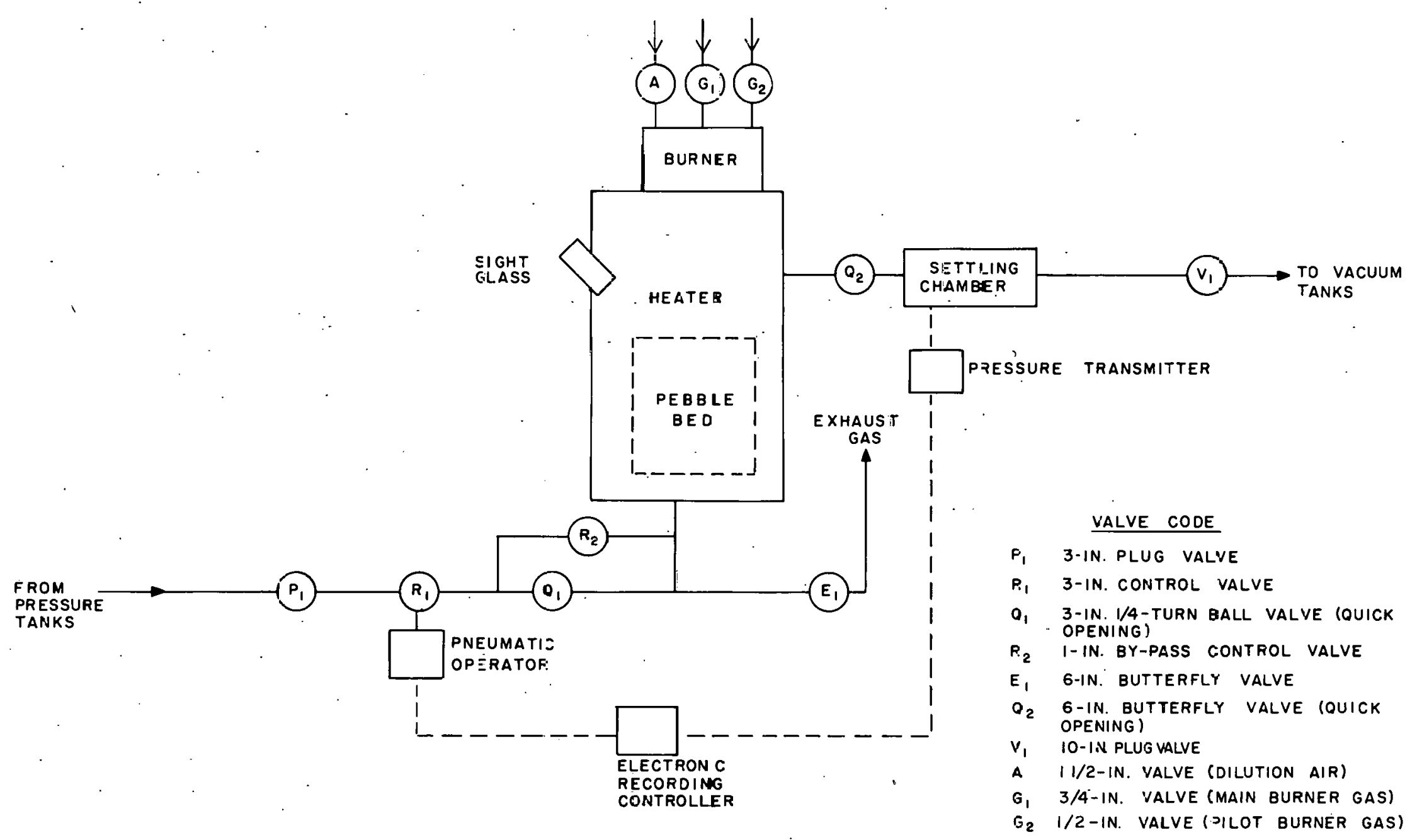

Figure 3. Schematic of j-inch Tunnel Pressidre Conirol System 


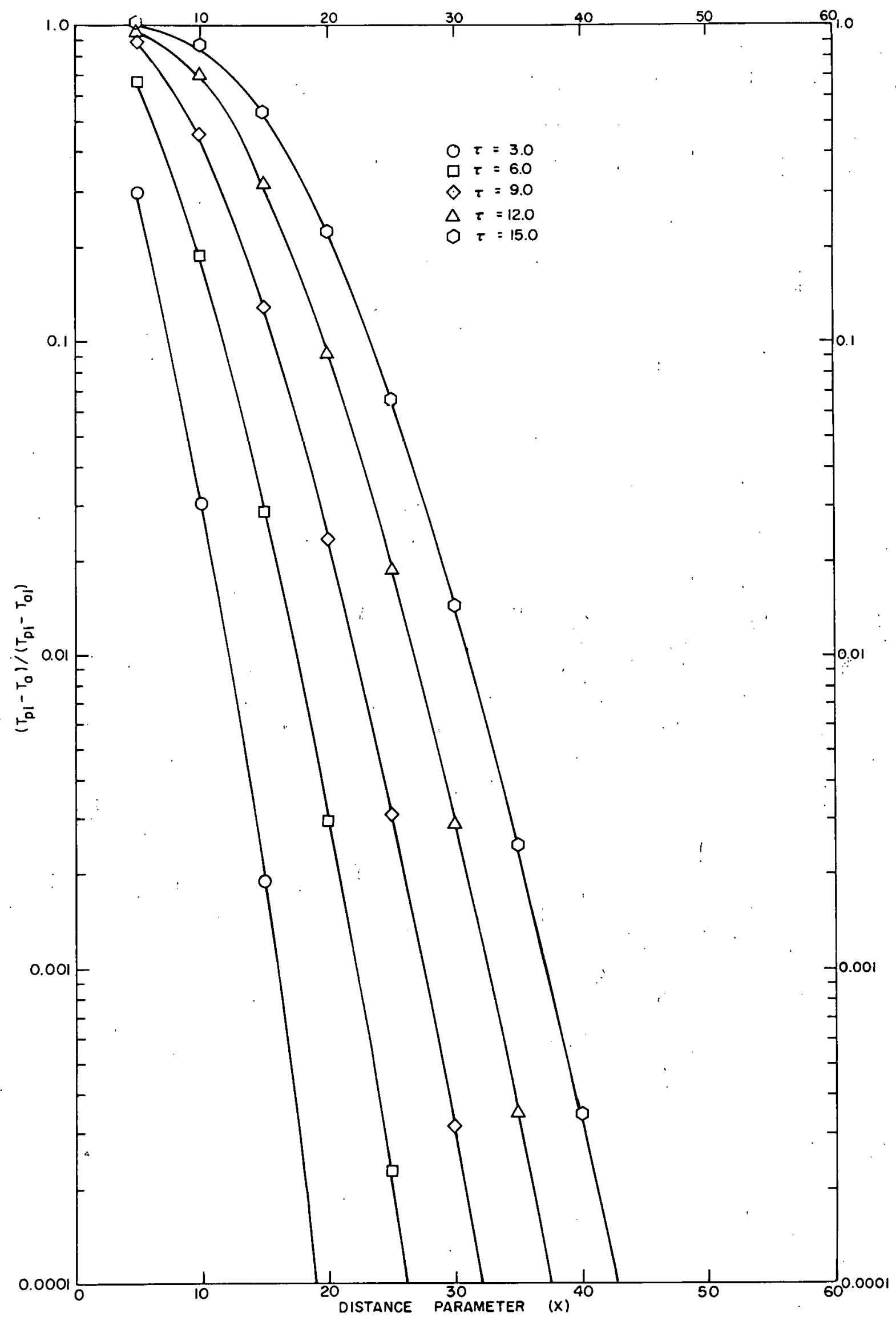

Figure 4. Variation of Air Temperature with Time and Distance Parameters 


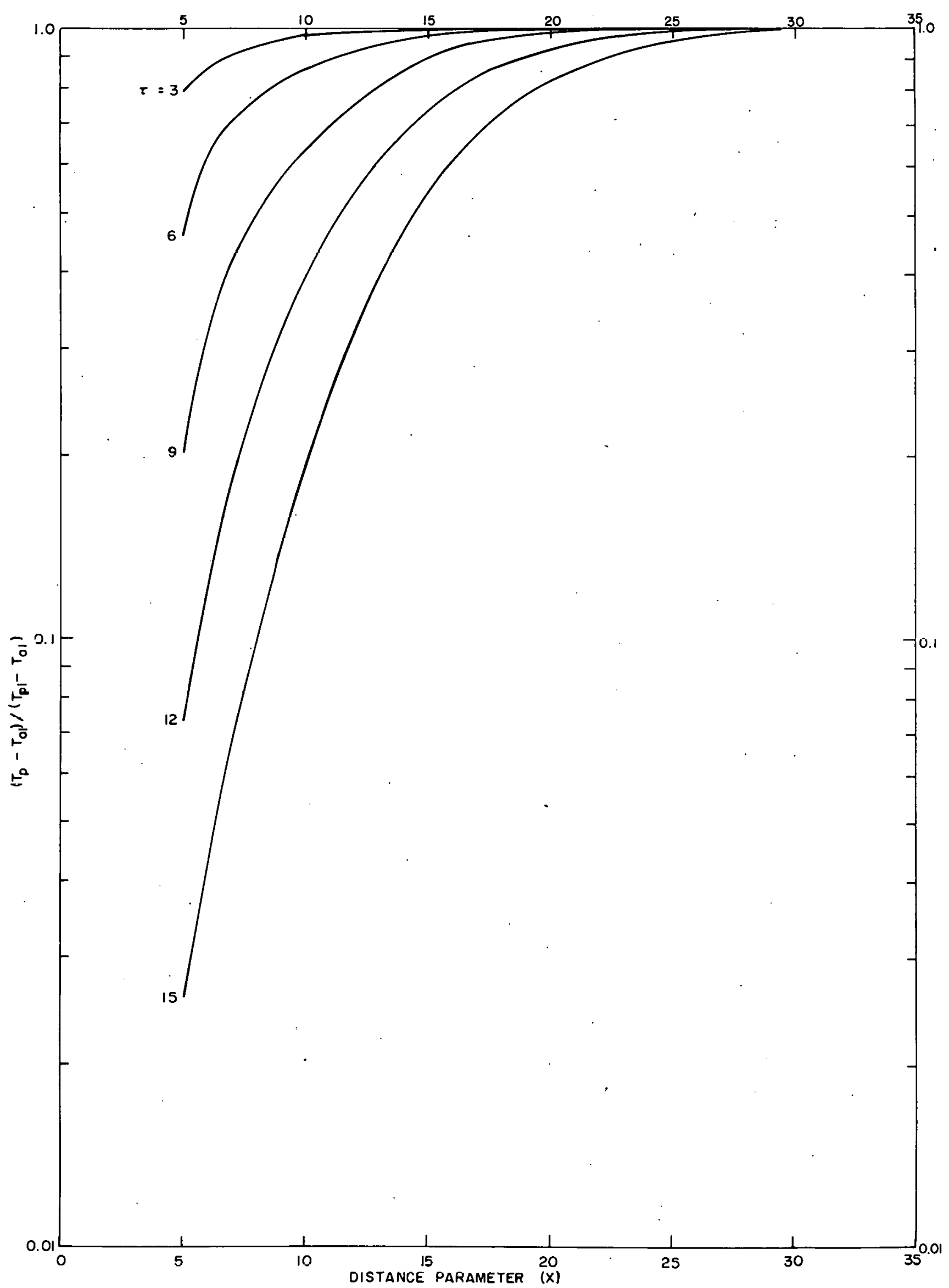

Figure 5. Variation of Pebble Temperature with Time and Distance Parameters 


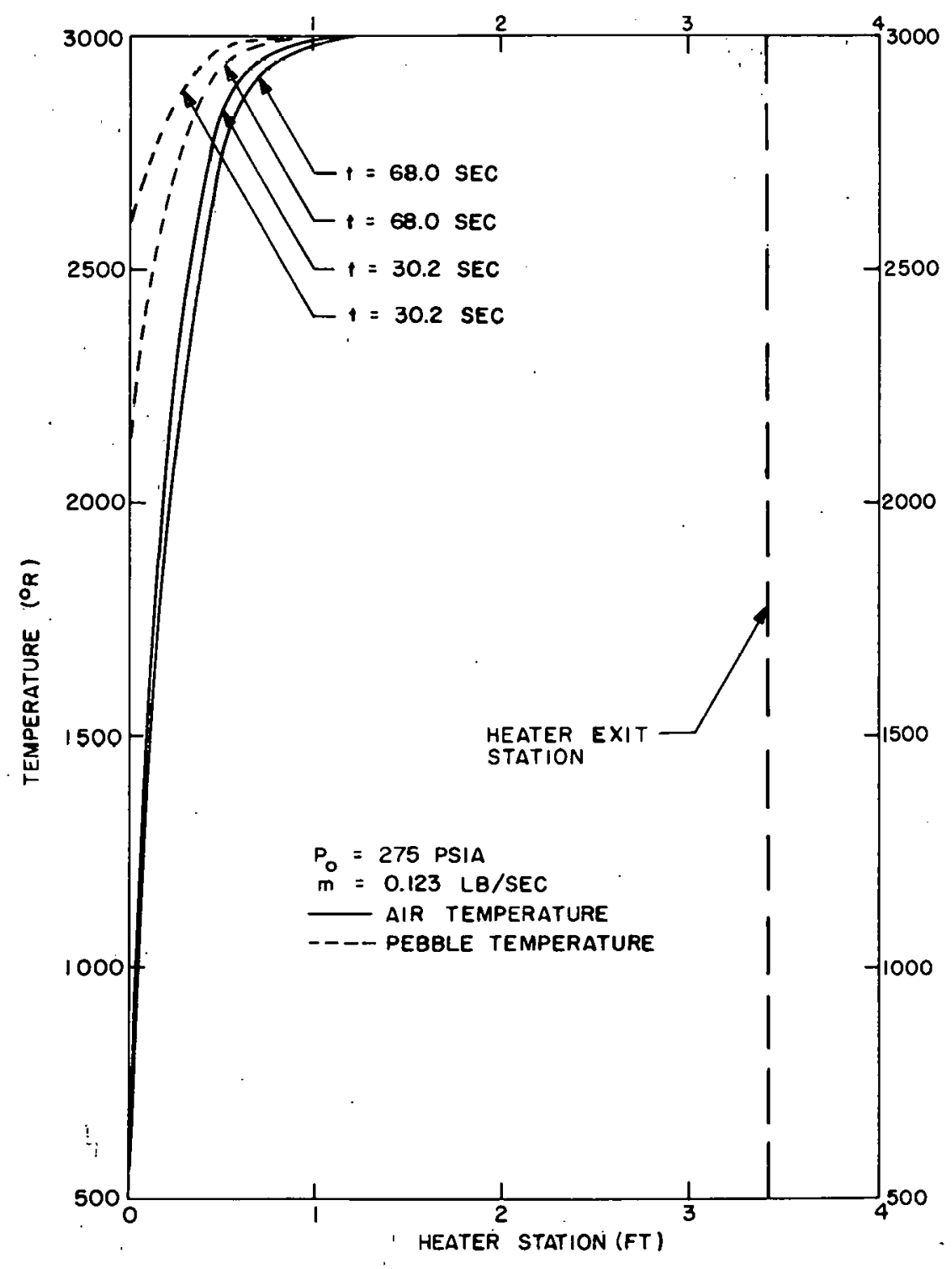

Figure 6. Variation of Pebble and Air Temperature with Time and Heater Station for an $M=9$ Nozzle 


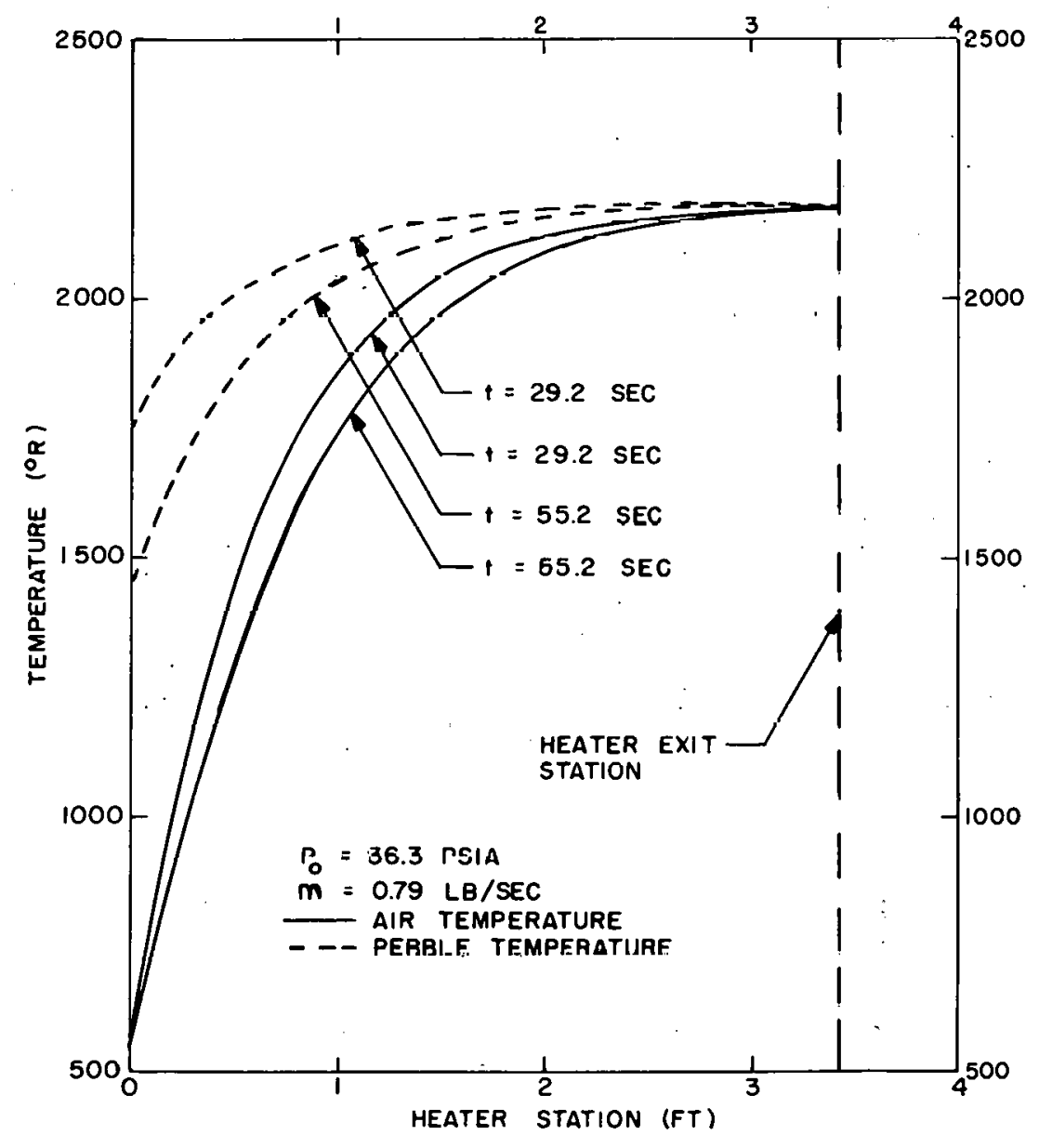

Figure 7. Variation of Pebble and Air Temperature with Time and Heater Station for an $M=4$ Nozzle 


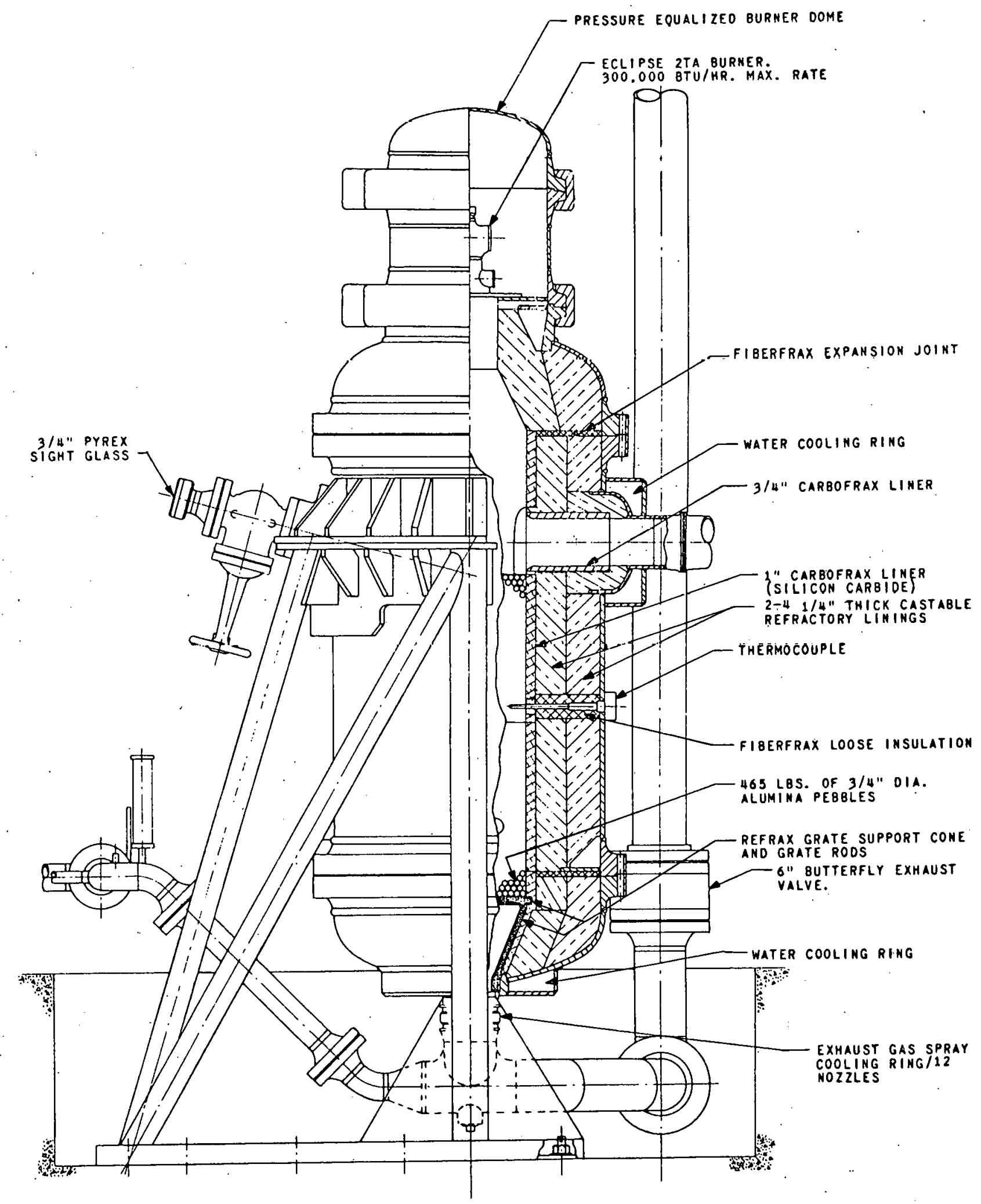

Figure 8. Elevation Sketch of Pebble-Bed Heater 


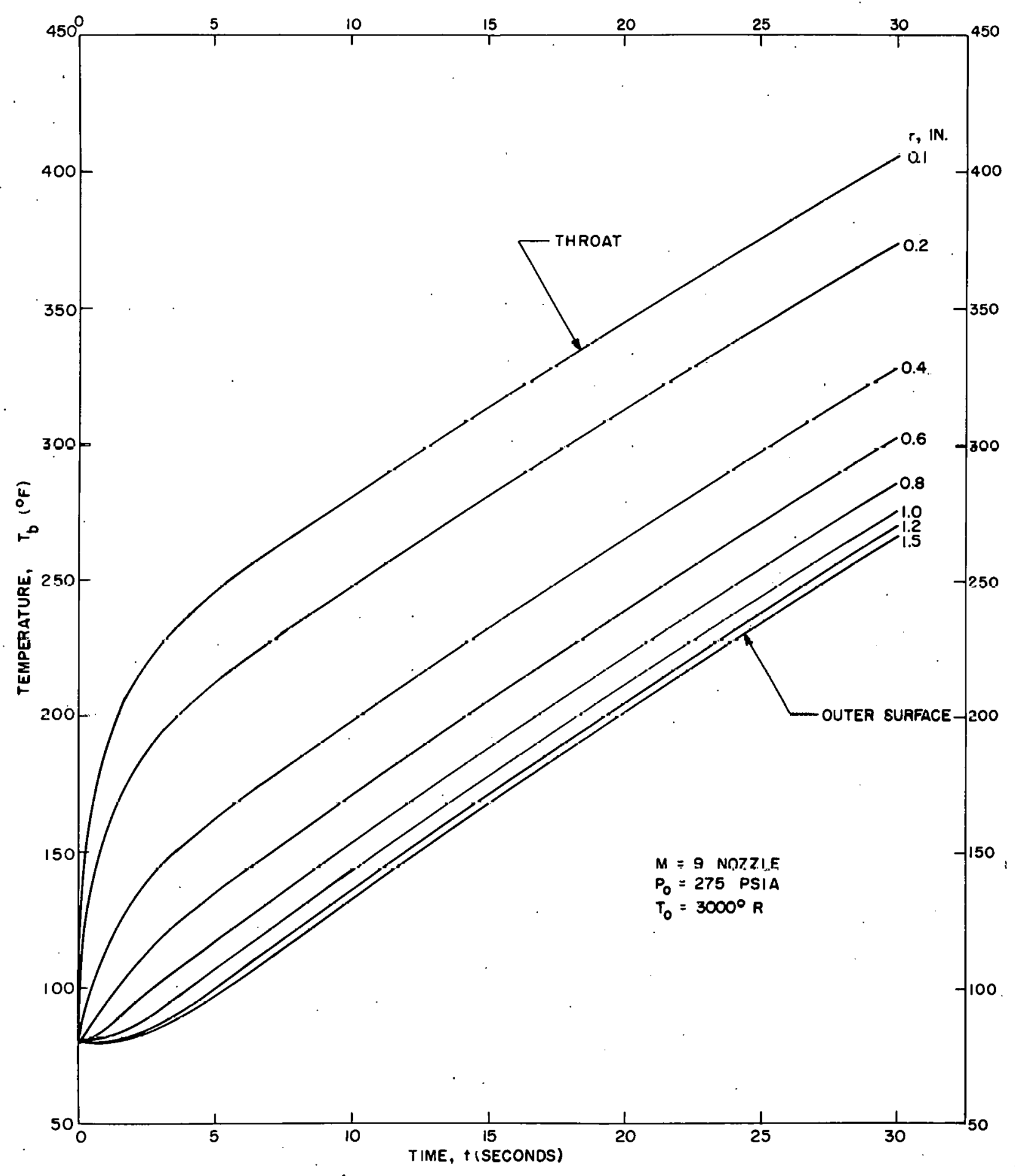

Figure 9. Variation of Temperature of Beryllium-Copper Throat with Run Time (No Water Conling) 


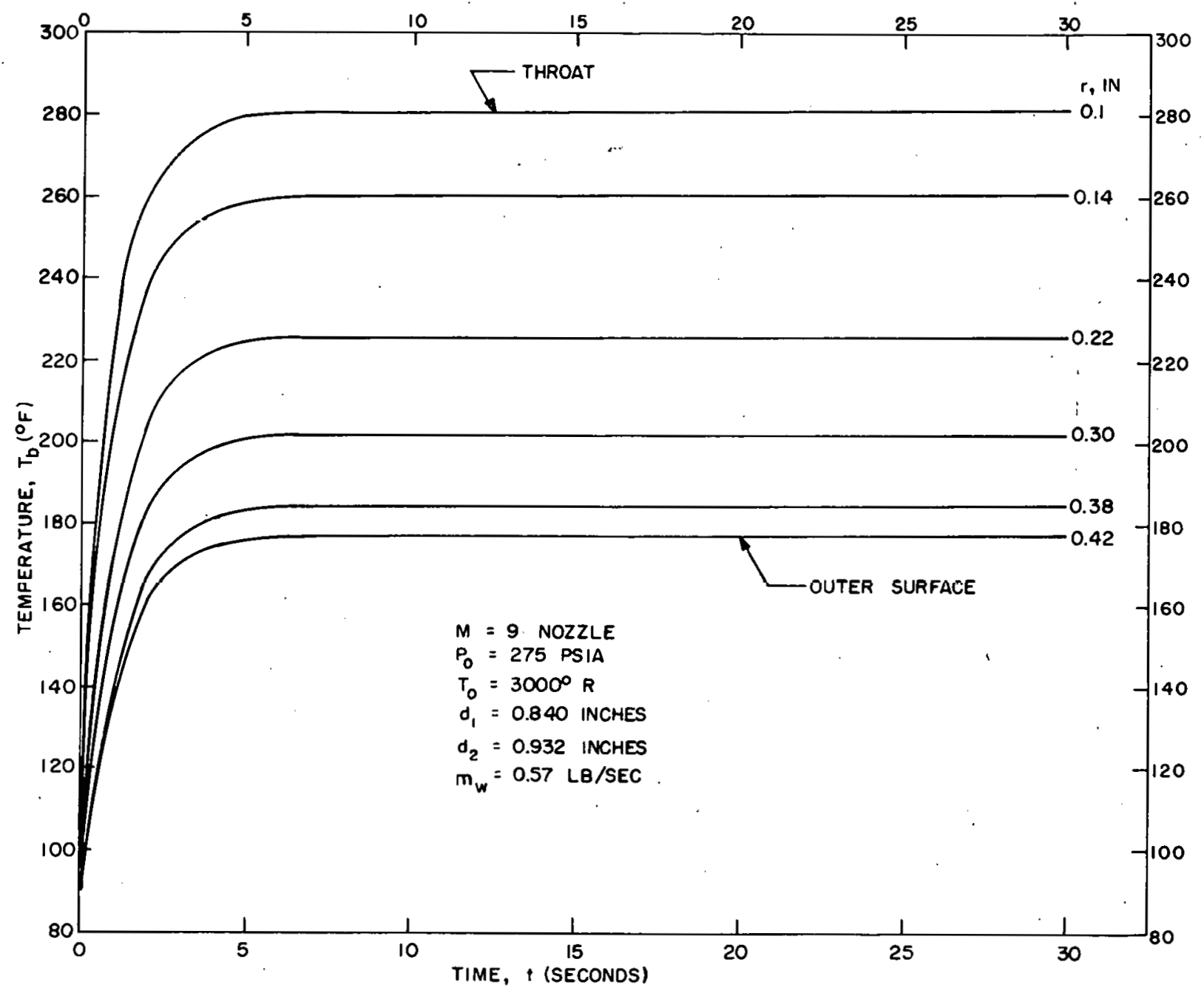

Figure 10. Variation of Temperature of Beryllium-Copper Throat with Run Time (With Water Cooling) 


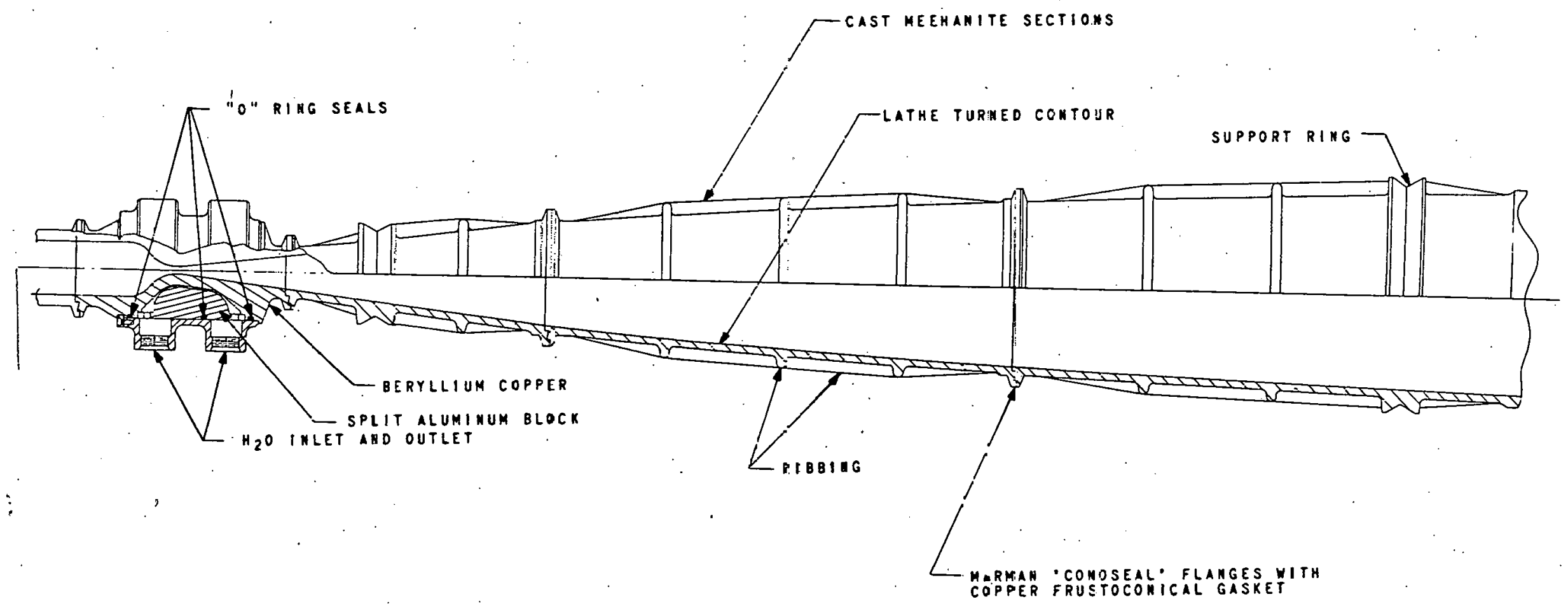

Figure 11. Sketck of Mach 9 Axisymmetric Water-Cooled Nozzle 